\title{
Petrogenesis of amphibole-rich ultramafic and its genetic relation with more evolved rocks: A case from the Hida metamorphic complex, Japan
}

\author{
KEITA ITANO $^{1 *}$, TOMOAKI MORISHITA ${ }^{1}$, IKUYA NISHIO ${ }^{1}$, \\ JUAN MiguEl GUOTANA ${ }^{1}$, AND AKIHIRO TAMURA ${ }^{1}$ \\ ${ }^{1}$ Kanazawa University \\ (corrspondence*: k.itano@staff.kanazawa-u.ac.jp)
}

Amphibole plays a key role in arc magma differentiation via crystal fractionation [1], although amphibole phenocryst is generally scarce in arc lavas. Amphibole-rich cumulates are potentially a counterpart of arc magma undergoing amphibole fractionation. Interestingly, amphibole-rich cumulates are ubiquitously found in arc regions, although the amphibole-rich ultramafic bodies are limited in volume. In this study, we conducted the petrological examination of amphibole-rich ultramafic rock in the Hida metamorphic complex, Japan for a better understanding of their role in arc crust differentiation. The studied sample is characterized by large poikilitic amphibole and orthopyroxene enclosing olivine grains, hereafter called a cortlandite. The olivine grains show resorbed textures. The olivine showed relatively homogeneous compositions with an average $\mathrm{Mg \#}$ $\left(\mathrm{Mg} /(\mathrm{Mg}+\mathrm{Fe})^{*} 100\right)$ of 84 . In contrast, poikilitic amphiboles (pargasite) and orthopyroxene yielded higher $\mathrm{Mg \#}$ of $\sim 85-89$ and $\sim 84-86$, respectively. Considering trace element chemistry and the results of previous experimental studies, the mineral assemblage of the studied sample suggests the crystallization of hydrous juvenile magma while consuming olivine $(+$ clinopyroxene). We found that the $\mathrm{SiO}_{2}$ contents of the plutonic rocks, including the studied cortlandite, in the Hida Belt positively and negatively correlated to $\mathrm{La} / \mathrm{Yb}$ and $\mathrm{Dy} / \mathrm{Yb}$, respectively. These correlations imply that the amphibole-rich plutonic rock was a counterpart of arc magma undergoing cryptic amphibole fractionation and contribute to arc crust evolution.

[1] Davidson J., Turner S., Handley H., Macpherson C. and Dosseto A., 2007. Amphibole "sponge" in arc crust?. Geology, 35 (9): 787-790. 